\title{
Dependence of Rapeseed Quality and Yield on Density, Variety and Year of Production
}

\author{
Milka Vujaković • Ana Marjanović-Jeromela • \\ Dušica Jovičić $\cdot$ Radovan Marinković
}

\begin{abstract}
Summary: Rapeseed is an important industrial plant in the world. In Vojvodina region of Serbia it is grown on well aerated and deep soils. Most often it is sown with the distance between the rows of $25 \mathrm{~cm}$, and 5-6 cm within the row. The trial with three winter rapeseed genotypes (Banaćanka, Slavica and NS-H-2) was set up at Rimski Šančevi (Vojvodina) during growing seasons of 2009/2010 and 2010/2011. Seed was sown with inter row spacing of $25 \mathrm{~cm}$, and spacing within the rows of $5 \mathrm{~cm}, 8 \mathrm{~cm}, 10 \mathrm{~cm}$ and $16 \mathrm{~cm}$. The following parameters were tested upon harvesting: seed germination, 1000 seed weight, test weight, seed yield, oil content and total protein in seed. No effect of planting density was observed on rapeseed seed quality produced in 2009/10 and 2010/11, which should be kept in mind when determining the quantity of seed required for sowing.
\end{abstract}

Keywords: planting density, rapeseed, seed quality, seed yield, variety

\section{Introduction}

Rapeseed is an important industrial plant in the world. It holds the third place among oily plants (FAOSTAT 2012). Areas under rapeseed kept increasing until 2009, when it was sown on 18,091 ha, in 2012 however the area was reduced to 8,258 ha, and in 2013 to 9,686 ha (RZS 2013). Reduction of areas under rapeseed was caused by the lack of moisture and high temperature during harvest, i.e. unfavourable conditions for germination and emergence, and fluctuations in the prices. Although this plant has various uses, it is most often used for oil extraction from seed. Due to its various forms and varieties it can be grown under various climatic regions. In order to obtain good seed quality, the rapeseed should be grown on well aerated and deep soils, with proper rainfall distribution, for it has a long vegetation period (Marjanović-Jeromela et al. 2007), although it gives more profitable yields compared to most other field crops grown on so called "marginal soils".

Optimal sowing date under our agroecological region ranges from 25 August to
20 September. It is sown in rows with the distance of $25 \mathrm{~cm}$, and the distance within the row of $5-6 \mathrm{~cm}$, which is consistent with density of $70-80$ plants $/ \mathrm{m}^{2}$ after emergence. In various regions across the globe, planting density of rapeseed ranges from $20-130$ plants $/ \mathrm{m}^{2}$ depending on production conditions and genotypes (Al-Barzinjy et al. 1999). With decrease in density the plants tend to branch and in that way compensate the lack of plants (Marjanović-Jeromela et al. 2006) - plants develop greater vegetative mass and greater number of seed coats per plant, which mature unevenly (Leach et al. 1999). Overly dense planting results in reduction of plant stem diameter and such plants tend to lodge (Marjanović-Jeromela et al. 2006) and are more susceptible to disease and pest attack (Leach et al. 1999). All these changes can negatively affect the quality and the yield of seed.

The aim of this investigation was to determine the influence of planting density on the seed quality (seed germination, 1000 seed weight and test weight), seed yield, oil and protein content of rapeseed seed produced in $2009 / 2010$ and 2010/2011. 


\section{Material and Methods}

The trial was set up in four replications with three rapeseed genotypes (Banaćanka, Slavica and NS$\mathrm{H}-2)$ on the trial field Rimski Šančevi of the Institute of Field and Vegetable Crops, Novi Sad $\left(45^{\circ} 20^{\prime} \mathrm{N}\right.$, 19०51' E, $80 \mathrm{~m}$ above sea level) in 2009/2010 and $2010 / 2011$. Sowing was performed on $4 \mathrm{~m}^{2}$ plots from 25 August 2009 and 26 September 2010 as the optimal sowing dates for rapeseed. Machines were used for sowing in rows with inter row spacing of 25 $\mathrm{cm}$ and distance within the row of $5 \mathrm{~cm}$ (80 plants/ $\left.\mathrm{m}^{2}\right), 6 \mathrm{~cm}\left(67\right.$ plants $\left./ \mathrm{m}^{2}\right), 8 \mathrm{~cm}\left(50\right.$ plants $\left./ \mathrm{m}^{2}\right), 10 \mathrm{~cm}$ $\left(40\right.$ plants $\left./ \mathrm{m}^{2}\right)$ and $16 \mathrm{~cm}\left(25\right.$ plants $\left./ \mathrm{m}^{2}\right)$. The following parameters were estimated upon harvesting: seed germination, weight of 1000 seeds, test weight, seed yield, oil content and total protein content in seed.

Seed germination and 1000 seed weight were determined using standard method according to ISTA Rules (ISTA 2010). Seed was germinated in Petri dishes/100 seed each, in four replications. Germination period was seven days at $20-30^{\circ} \mathrm{C}$. Testing was performed in the Laboratory for seed testing, Institute of Field and Vegetable Crops, Novi Sad and Agricultural station, Novi Sad.

Oil content was determined using NMR method, and the content of total protein using Kjeldahl method in Oil Crops Department, Institute of Field and Vegetable Crops, Novi Sad. Seed yield and test weight were determined by weighing on the scales.

The obtained results were statistically processed by applying variance and correlation analyses using the MSTAT-C software. Significant difference between means was calculated by Duncan test $(\mathrm{p}<0.05)$.

\section{Results and Discussion}

Germination of seed produced in 2009/2010 was high in all tested varieties and ranged from 94.5 to $98.0 \%$ (Tab. 1). Somewhat lower values of the tested parameter were obtained in 2010/11 and ranged from 90.75 to $94.50 \%$. In both years seed germination was higher than the minimum value described $(75 \%)$ by the Rule on quality of seed of agricultural plants (Official Gazette SFRJ 47/87). The effect of variety and sowing density on the tested parameter was not determined by the variance analysis. However, the effect of variety on seed germination was determined by Jovičić et al. (2011). Correlation analysis was used to determine negative correlation dependence between production year $(\mathrm{r}=$ $\left.0.53^{*}\right)$, oil content $\left(\mathrm{r}=-0.31^{*}\right)$, seed yield $\left(\mathrm{r}=-0.46^{*}\right)$, test weight $\left(\mathrm{r}=-0.37^{*}\right), 1000$ seed weight $\left(\mathrm{r}=-0.45^{*}\right)$, and seed germination, while no correlation dependence was found between tested parameter and genotype, and planting density (Tab. 2). Dependence of seed germination on the production year was determined by Elias and Copeland (2001).

Thousand seed weight of rapeseed produced in 2009/10 ranged between 3.47 and $4.08 \mathrm{~g}$ (Tab. 1). In seed produced in 2010/11, 1000 seed weight was higher and ranged from 4.38 to 5.25 g. Statistically significant difference was found only in Slavica variety in 2010/11, which had statistically higher value at density of 25 plant $/ \mathrm{m}^{2}$ in relation to other tested densities. Varieties Slavica and Banaćanka had statistically significantly lower values of the tested parameters for seed produced in 2009/10 in relation to seed produced in 2010/11, while for hybrid NS-H2 no statistically significant differences were obtained. Low temperatures and frost in January 2010, and a long rain period in May and June in 2009/10 were unfavourable for rapeseed production compared to 2010/11 (Figures 1 and 2), and it is considered to be the main reason for the lower values of the tested parameters obtained for seed produced in 2009/10. The influence of production year and variety on the tested parameter was determined, while the influence of planting density failed to be determined, which was in accordance with the results obtained by Soleymani et al. (2011a). Negative correlation ratio between 1000 seed weight and total protein content $\left(\mathrm{r}=-0.24^{*}\right)$ and test weight $\left(\mathrm{r}=-0.77^{*}\right)$ was determined (Tab. 2). Positive correlation ratio between 1000 seed weight and production year $\left(\mathrm{r}=0.73^{*}\right)$ and oil content $\left(\mathrm{r}=0.27^{*}\right)$ was determined.

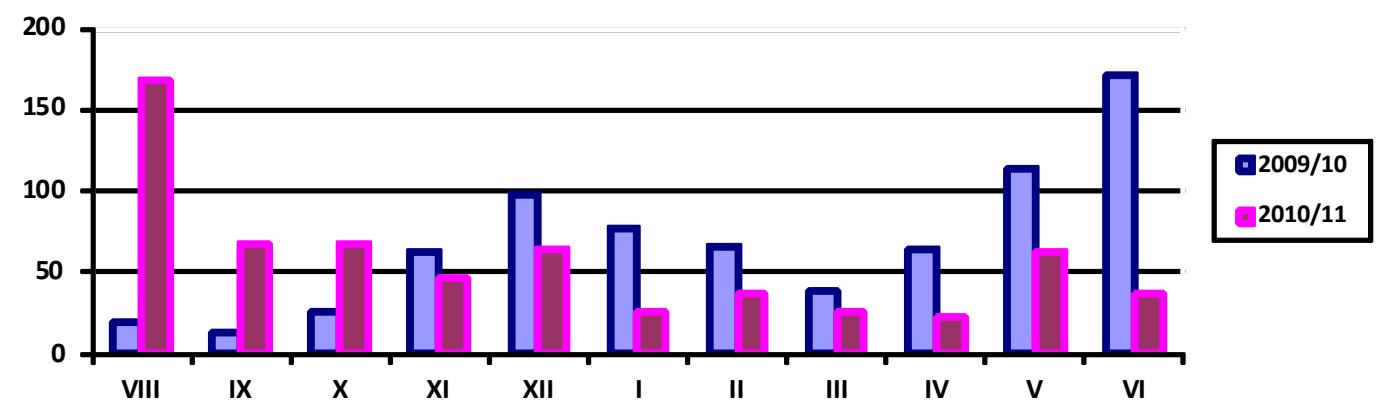

Figure 1. Rainfall participation in 2009/2010 and 2010/2011 (Rimski Šančevi) 
Table 1. Mean values regarding seed germination, 1000 seed weight, test weight, seed yield, oil and protein content of rapeseed varieties produced at different plant density during 2009/10 and 2010/11 growing season

\begin{tabular}{|c|c|c|c|c|c|c|c|c|}
\hline $\begin{array}{l}\text { Vegetation } \\
\text { period }\end{array}$ & Variety & $\begin{array}{c}\text { Planting } \\
\text { density } \\
\text { (plant/ } \\
\mathrm{m}^{2} \text { ) }\end{array}$ & $\begin{array}{c}\text { Seed } \\
\text { germination } \\
(\%)\end{array}$ & $\begin{array}{l}1000 \text { seed } \\
\text { weight }\end{array}$ & Test weight & $\begin{array}{l}\text { Seed } \\
\text { yield }\end{array}$ & $\begin{array}{c}\text { Oil } \\
\text { content }\end{array}$ & $\begin{array}{l}\text { Total } \\
\text { protein } \\
\text { content }\end{array}$ \\
\hline \multirow{15}{*}{$2009 / 10$} & \multirow{5}{*}{ Banaćanka } & 80 & $95.00 \mathrm{a}-\mathrm{f}$ & $4.01 \mathrm{c}-\mathrm{h}$ & $65.58 \mathrm{fg}$ & $0.56^{\mathrm{e}}$ & $42.70^{\mathrm{a}-\mathrm{e}}$ & $21.40^{\mathrm{a}-\mathrm{d}}$ \\
\hline & & 67 & $95.00 \mathrm{a}-\mathrm{f}$ & $3.92 \mathrm{~d}-\mathrm{h}$ & $65.65 \mathrm{fg}$ & $0.60 \mathrm{e}$ & $41.60^{e}$ & 20.94a-h \\
\hline & & 50 & $95.50^{a-f}$ & $3.92 \mathrm{~d}-\mathrm{h}$ & $65.45^{\mathrm{gh}}$ & $0.67^{e}$ & 42.00 de & 21.09 a-e \\
\hline & & 40 & $96.00^{\mathrm{a}-\mathrm{e}}$ & $3.82^{\mathrm{gh}}$ & $65.50 \mathrm{~g}$ & $0.85^{\mathrm{e}}$ & $42.98^{\mathrm{a}-\mathrm{e}}$ & $20.80^{a-i}$ \\
\hline & & 16 & $96.75^{\mathrm{a}-\mathrm{c}}$ & $3.69^{h}$ & $65.80^{\mathrm{fg}}$ & $0.75^{\mathrm{e}}$ & $42.05^{\mathrm{de}}$ & $21.06^{a-f}$ \\
\hline & \multirow{5}{*}{ Slavica } & 80 & $95.52 \mathrm{a}-\mathrm{f}$ & $3.84 \mathrm{gh}$ & $66.10^{\mathrm{fg}}$ & $0.70 \mathrm{e}$ & $42.17 \mathrm{c}-\mathrm{e}$ & $21.00^{a-g}$ \\
\hline & & 67 & $96.50^{\mathrm{a}-c}$ & $3.68^{\mathrm{h}}$ & $66.35^{f}$ & $0.61^{\mathrm{e}}$ & $42.43^{\mathrm{b}-\mathrm{e}}$ & $20.10^{c-k}$ \\
\hline & & 50 & $94.50^{a-g}$ & $3.68^{\mathrm{h}}$ & $66.25^{\mathrm{fg}}$ & $0.57^{\mathrm{e}}$ & $42.32^{\mathrm{b}-\mathrm{e}}$ & $20.72^{a-j}$ \\
\hline & & 40 & $98.00^{a}$ & $3.52^{\mathrm{h}}$ & $66.25 \mathrm{fg}$ & $0.54 \mathrm{e}$ & $43.00^{a-e}$ & $19.78^{\mathrm{e}-\mathrm{k}}$ \\
\hline & & 16 & $97.00^{\mathrm{ab}}$ & $3.47 \mathrm{~h}$ & 66.10fg & $0.72 \mathrm{e}$ & $42.32^{\mathrm{b}-\mathrm{e}}$ & $19.74 \mathrm{e}-\mathrm{k}$ \\
\hline & \multirow{5}{*}{ NS-H-R-2 } & 80 & $94.50^{\mathrm{a}-\mathrm{g}}$ & $4.03 \mathrm{~d}-\mathrm{h}$ & $64.20^{\mathrm{i}}$ & $0.65^{\mathrm{e}}$ & $42.25^{\mathrm{b}-\mathrm{e}}$ & $21.73^{\mathrm{ab}}$ \\
\hline & & 67 & $95.00^{\mathrm{a}-\mathrm{f}}$ & $4.02 \mathrm{~d}-\mathrm{h}$ & $64.35^{\mathrm{i}}$ & $0.79 \mathrm{e}$ & $42.26^{\mathrm{b}-\mathrm{e}}$ & $22.01^{a}$ \\
\hline & & 50 & $96.25^{\mathrm{a}-\mathrm{d}}$ & $3.95^{c-h}$ & $64.73^{\mathrm{hi}}$ & $0.71^{\mathrm{e}}$ & $42.24^{\mathrm{b}-\mathrm{e}}$ & $21.44^{\mathrm{a}-\mathrm{c}}$ \\
\hline & & 40 & $95.50 \mathrm{a}-\mathrm{f}$ & $3.87^{\mathrm{f}-\mathrm{h}}$ & $64.75^{\mathrm{i}}$ & $0.93^{c-e}$ & $43.05^{\mathrm{a}-\mathrm{e}}$ & $21.68^{a-c}$ \\
\hline & & 16 & $95.75 \mathrm{a}-\mathrm{f}$ & $4.08^{\mathrm{c}-\mathrm{h}}$ & $64.20^{\mathrm{i}}$ & $0.94 c-e$ & $42.68^{a-e}$ & $21.77 \mathrm{a}$ \\
\hline \multirow{15}{*}{ 2010/11 } & \multirow{5}{*}{ Banaćanka } & 80 & $90.75 \mathrm{~g}$ & $4.85^{\mathrm{ab}}$ & $67.30 \mathrm{e}$ & $1.65^{\mathrm{ab}}$ & $44.36^{\mathrm{a}-\mathrm{c}}$ & $20.49 a-k$ \\
\hline & & 67 & $91.50^{\mathrm{fg}}$ & $4.78^{\mathrm{ab}}$ & $67.40^{\mathrm{de}}$ & $1.52^{\mathrm{ab}}$ & $43.75^{\mathrm{a}-\mathrm{e}}$ & $19.33^{\mathrm{h}-\mathrm{k}}$ \\
\hline & & 50 & $92.50^{c-g}$ & $4.71^{\mathrm{ab}}$ & $67.70^{\mathrm{b}-\mathrm{e}}$ & $1.34^{\mathrm{cd}}$ & $43.39^{\mathrm{a}-\mathrm{e}}$ & $19.77 \mathrm{~d}-\mathrm{k}$ \\
\hline & & 40 & $93.50^{b-g}$ & $4.65^{b c}$ & $67.70^{\mathrm{b}-\mathrm{e}}$ & $1.62^{\mathrm{ab}}$ & $42.86^{\mathrm{a}-\mathrm{e}}$ & $19.21^{\mathrm{i}-\mathrm{k}}$ \\
\hline & & 16 & $92.00 \mathrm{~d}-\mathrm{g}$ & $4.83^{\mathrm{ab}}$ & $68.10^{a-e}$ & $1.70^{\mathrm{ab}}$ & $42.86^{\mathrm{a}-\mathrm{e}}$ & $20.13 \mathrm{~b}-\mathrm{k}$ \\
\hline & \multirow{5}{*}{ Slavica } & 80 & 93.25 b-g & $4.48^{\mathrm{b}-\mathrm{e}}$ & $68.20^{\mathrm{a}-\mathrm{d}}$ & $1.38^{\mathrm{b}}$ & $43.78^{\mathrm{a}-\mathrm{e}}$ & $19.05^{\mathrm{k}}$ \\
\hline & & 67 & $94.50^{a-g}$ & $4.38^{\mathrm{b}-\mathrm{e}}$ & $68.50^{\mathrm{ab}}$ & $1.67 \mathrm{ab}$ & $43.80^{\mathrm{a}-\mathrm{e}}$ & $19.12^{\mathrm{j}}$ \\
\hline & & 50 & 93.50 b-g & 4.52 b-e & $68.75^{a}$ & $1.89 \mathrm{a}$ & $43.45^{\mathrm{a}-\mathrm{e}}$ & $19.53^{\mathrm{e}-\mathrm{k}}$ \\
\hline & & 40 & $93.25^{b-g}$ & $4.53^{\mathrm{b}-\mathrm{e}}$ & $68.15^{\mathrm{a}-\mathrm{d}}$ & $1.61^{\mathrm{ab}}$ & $43.99^{\mathrm{a}-\mathrm{d}}$ & $19.41^{\mathrm{g}-\mathrm{k}}$ \\
\hline & & 16 & $92.00 \mathrm{~d}-\mathrm{g}$ & $5.25^{\mathrm{a}}$ & $68.40^{a-c}$ & $1.39 \mathrm{~b}$ & $43.84^{\mathrm{a}-\mathrm{e}}$ & $19.43^{\mathrm{f}-\mathrm{k}}$ \\
\hline & \multirow{5}{*}{ NS-H-R-2 } & 80 & $92.00 \mathrm{~d}-\mathrm{g}$ & $4.63 \mathrm{bc}$ & $67.90^{\mathrm{b}-\mathrm{e}}$ & $1.34 \mathrm{~b}-\mathrm{d}$ & $44.91^{\mathrm{a}}$ & $19.68^{\mathrm{e}-\mathrm{k}}$ \\
\hline & & 67 & $94.00^{a-g}$ & $4.54^{\mathrm{b}-\mathrm{d}}$ & $67.65^{\mathrm{c}-\mathrm{e}}$ & $1.43^{\mathrm{ab}}$ & $44.46^{\mathrm{ab}}$ & $19.27^{\mathrm{i}-\mathrm{k}}$ \\
\hline & & 50 & 93.50 b-g & $4.45 \mathrm{~b}-\mathrm{f}$ & $67.75^{\mathrm{b}-\mathrm{e}}$ & $1.60 \mathrm{ab}$ & $44.48^{\mathrm{ab}}$ & $20.09 \mathrm{c}-\mathrm{k}$ \\
\hline & & 40 & $94.00^{\mathrm{a}-\mathrm{g}}$ & 4.39 b-e & $67.65^{\mathrm{c}-\mathrm{e}}$ & $1.51^{\mathrm{ab}}$ & $44.70^{\mathrm{a}}$ & $19.53^{\mathrm{e}-\mathrm{k}}$ \\
\hline & & 16 & 91.75 e-g & $4.42^{\mathrm{b}-\mathrm{e}}$ & $67.45^{\mathrm{de}}$ & $1.87 \mathrm{a}$ & $44.73^{a}$ & $19.80 \mathrm{~d}-\mathrm{k}$ \\
\hline
\end{tabular}


Table 2. Correlation ratio

\begin{tabular}{lcccccc}
\hline & $\begin{array}{c}\text { Seed } \\
\text { germination }\end{array}$ & $\begin{array}{c}1000 \text { seed } \\
\text { weight }\end{array}$ & $\begin{array}{c}\text { Test } \\
\text { weight }\end{array}$ & $\begin{array}{c}\text { Seed } \\
\text { yield }\end{array}$ & $\begin{array}{c}\text { Oil } \\
\text { content }\end{array}$ & $\begin{array}{c}\text { Total protein } \\
\text { content }\end{array}$ \\
\hline Year & $-0.53^{*}$ & $0.73^{*}$ & $0.86^{*}$ & $0.84^{*}$ & $0.53^{*}$ & $-0.58^{*}$ \\
Genotype & 0.06 & -0.06 & -0.16 & 0.04 & $0.20^{*}$ & 0.09 \\
Planting density & 0.11 & -0.03 & 0.03 & 0.12 & -0.02 & -0.06 \\
Total protein content & 0.17 & $-0.24^{*}$ & $-0.60^{*}$ & $-0.40^{*}$ & $-0.60^{*}$ & \\
Oil content & $-0.31^{*}$ & $0.27^{*}$ & $0.35^{*}$ & $0.35^{*}$ & & \\
Seed yield & $-0.46^{*}$ & $0.61^{*}$ & $0.74^{*}$ & & & \\
Test weight & $-0.37^{*}$ & $-0.77^{*}$ & & & & \\
Weight of 1000 seeds & $-0.45^{*}$ & & & & & \\
\hline
\end{tabular}

(significance threshold $\mathrm{p}<0.05$ )

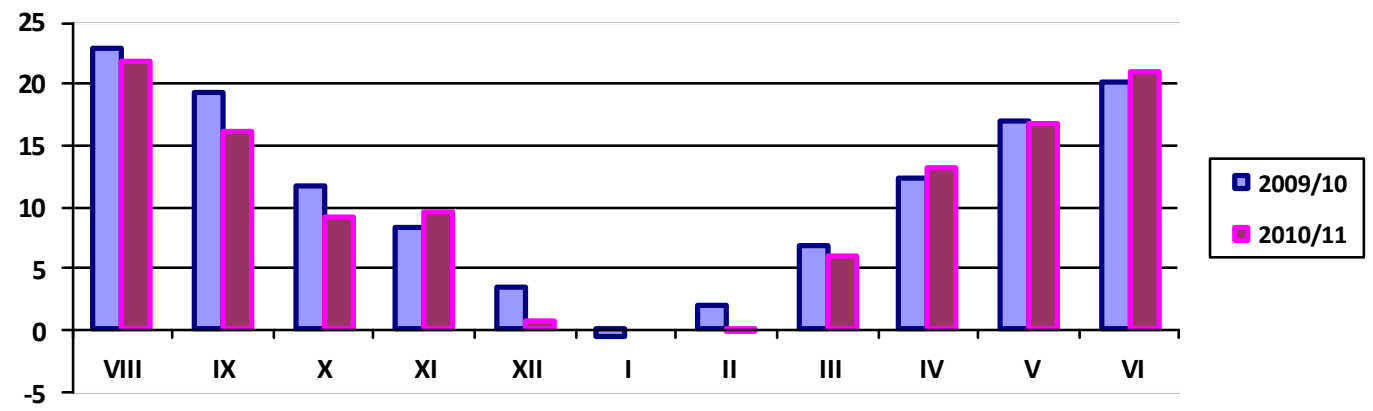

Figure 2. Mean monthly temperatures in 2009/2010 and 2010/2011 (Rimski Šančevi)

In $2009 / 10$ the test weight ranged from 64.20 to $66.35 \mathrm{~kg}$ (Tab. 1). Hybrid NS-H-2 had statistically significantly lower values for all tested densities compared to varieties Banaćanka and Slavica. Test weight of the seed produced in 2010/11 was statistically significantly higher compared to the seed produced in 2009/10. The values of the tested parameter for seed produced in 2010/11 ranged from 67.30 to $68.75 \mathrm{~kg}$, and there were no statistically significant differences among tested varieties and densities. High positive correlation dependency between test weight and production year $\left(\mathrm{r}=0.86^{*}\right)$, as well as between the test weight and other tested parameters (total protein content $\mathrm{r}=-0.60^{*}$, oil content $\mathrm{r}=0.35^{*}$, seed yield $\mathrm{r}=0.74^{*}$ ) was determined (Tab. 2). The influence of the production year on test weight was determined by Vujaković et al. (2014).

Seed yield per plot in 2009/10 (0.54-0.94 kg/ plot) for all tested varieties was statistically significantly lower compared to seed obtained in 2010/11 (1.34-1.89 kg/plot) (Tab. 1). In 2010/11 statistically significantly lower yield was obtained for hybrid NS-H-2 at density of 80 plant $/ \mathrm{m}^{2}$ compared to yield obtained at density of $16 \mathrm{plant} / \mathrm{m}^{2}(1.87 \mathrm{~kg} /$ plot), while for variety Slavica at density of 80 plant/ $\mathrm{m}^{2}(1.38 \mathrm{~kg} / \mathrm{plot})$ and 16 plants $/ \mathrm{m}^{2}(1.39 \mathrm{~kg} / \mathrm{plot})$ statistically significantly lower yield was obtained compared to the yield obtained at density of 50 plants $/ \mathrm{m}^{2}(1.89 \mathrm{~kg} / \mathrm{plot})$. The absence of statistically significant differences in the yield of seed produced at various densities, or even achievement of higher seed yield at lower density, revealed that plants obtained at low density compensated for the lack of plants by producing more branches. This finding should be kept in mind when determining the quantity of seed required for sowing. On the other hand, Zhang et al. (2012) showed that the yield of rapeseed seed significantly decreased with the increase of planting density, and claimed that planting density primarily influenced the lateral branches, and less the development of the main stem. Significant positive correlation dependence between production year and seed yield $\left(\mathrm{r}=0.84^{*}\right)$, as well as the significant negative dependence of seed yield and total protein content $\left(\mathrm{r}=-0.40^{*}\right)$ were determined (Table 2$)$. The influence of production year on seed yield was determined by Vujaković et al. (2010), while Marinković et al. (2011) claimed that planting density in rapeseed plays a significant role in achieving desired yield, which was not confirmed by our investigation. 
The content of oil in rapeseed seed produced in 2009/10 ranged from 41.60 to $43.05 \%$ (Tab. 1). Among all tested variants there were no statistically significant differences. Somewhat higher values of the tested parameter, but not statistically significant, were obtained in 2010/11 (42.86-44.91\%). Some differences, not statistically significant, were noticed among varieties. Correlation analysis was used to determine significant negative ratio between oil and protein contents $\left(\mathrm{r}=-0.60^{*}\right)$ (Tab. 2). Positive correlation ratio between the oil content and production year $\left(\mathrm{r}=0.53^{*}\right)$ and genotype $\left(\mathrm{r}=0.20^{*}\right)$ was determined. The influence of density on the tested parameter was not determined by the correlation analysis. Ozer (2003) and Soleymani et al. (2011b) stated that higher oil content was found in the seed produced at lower density compared to higher density, but those differences were not statistically significant.

Protein content in seed produced in 2009/10 ranged from 19.74 to $22.01 \%$, and in 2010/11 from 19.05 to $20.49 \%$ (Tab. 1). Variety NS-H-2 had statistically significantly higher values of the tested parameter in seed produced in 2009/10 compared to values obtained in 2010/11. Correlation dependence of total protein content and density $(r=-0.06)$ and genotype $(r=0.09)$ was not confirmed by correlation analysis, while among total protein content and production year $\left(\mathrm{r}=-0.58^{*}\right)$ a significant negative correlation ratio was obtained (Table 2). Our studies failed to confirm the influence of genotype on protein content determined by Marinković et al. (2010), while Shrief et al. (1990) determined higher protein content in seed obtained at higher density. Negative correlation ration between protein content and oil was determined by Hao et al. (2004), which was confirmed by our investigation.

\section{Conclusions}

Germination of seed in both investigation years was significantly higher than the minimal values prescribed by the Rule. Thousand seed weight depended on the production year and variety, while the influence of the planting density on the tested parameter was not determined. Test weight also depended on the production year. In 2009/10 the hybrid NS-H-2 had statistically significantly lower values for all tested densities compared to varieties Banaćanka and Slavica, while these differences were not confirmed in 2010/11.

Seed yield per plot in 2009/10 for all tested varieties was statistically significantly lower compared to the seed yield obtained in 2010/11. Oil content in seed was somewhat higher, but not statistically significant in the seed produced in 2010/11 compared to the values obtained in 2009/10. There were also differences among varieties, but they were not statistically significant. Protein content was higher, but not statistically significant in the seed produced in $2009 / 10$.

Correlation analysis revealed significant correlation dependence between production year and tested parameters, while no correlation dependence was observed between density and tested parameters. The effect of density on quality of rapeseed seed produced in 2009/10 and 2010/11 was not determined, which should be kept in mind when determining the quantity of seed required for sowing.

\section{References}

Al-Barzinjy, M., Stolen, O., Christiansen, J.L., \& Jensen, J.E. (1999). Relationship between plant density and yield for two spring cultivars of oilseed rape (Brassica napus L.). Acta Agr. Scand. Sect. B, Soil Plant Sci., 49, 129-133.

Elias, S. G., \& Copeland, L., O. (2001). Physiological and harvest maturity of canola in relation to seed quality. Agron. J., 93, 1054-1058.

Hao, X., Chang, C., \& Travis, G. J. (2004). Short communication: effect of long-term cattle manure application on relations between nitrogen and oil content in content in canola seed. J. Plant Nutr. Soil Sci., 167, 214215.

FAO (2012). FAOSTAT. Food and Agriculture Organization of United Nation (http:// faostat.fao.org/).

ISTA (2010). International Rules for Seed Testing, International Seed Testing Association, Switzerland.

Jovičić, D., Marjanović-Jeromela, A., Vujaković, M., Marinković, R., Sakač, Z., Nikolić, Z., \& Milošević, B. (2011). Uticaj različitih doza NPK đubriva na kvalitet semena uljane repice. Ratar. Porrt., 48, 125-130.

Leach, J. E., Stevenson, H. J., Rainbow, A. J., \& Mullen, L. A. (1999). Effects of high plant populations on the growth and yield of winter oilseed rape (Brassica napus). J. Agric. Sci., Cambridge, 132, 173-180.

Marinković, R., Marjanović-Jeromela, A., Mitrović, P., \& Milovac, Ž. (2010). Uljana repica (Brassica napus L.) kao proteinska bilina vrsta. Ratar Pourt. 47, 157-161.

Marinković, R., Marjanović-Jeromela, A., \& Đilvesi, K (2011). Semenska proizvodnja ozime uljane repice. pp. 445-514. In: M. Milošević, B. Kobiliski (eds.) Semenarstıo, Vol. II. Institute of Field and Vegetable Crops, Novi Sad.

Marjanović-Jeromela, A., Marinković, R., \& Furman, T. (2006). Uljana repica kao sirovina za proizvodnju biodizela. Zbornik radova Naućnog Instituta za ratarstuo i pourtarstuo, Novi Sad, 42, 25-39.

Marjanović-Jeromela, A., Marinković, R., \& Mitrović, P. (2007). Oplemenjivanje uljane repice (Brassica napus L.). Zbornik radova Instituta za ratarstuo i povrtarstuo, Novi Sad, 43, 139-148.

Ozer, H. (2003): The effect of plant population densities on growth, yield and yield components of two spring rapeseed cultivars. Plant Soil Environ., 49(9), 422-426.

Republic of Yugoslavia (1987): Rule on quality of seed of agricultural plants. Official Gazette SFRJ, 47/87.

Republički zavod za statistiku RZS (2013). Statistički podaci. RSZ, Belgrade (http://webrzs.stat.gov.rs/WebSite/public/ReportView.aspx).

Shrief, S.A., Shabana, R., Ibrahim, A.F., \& Geisler, G. (1990). Variation in seed yield and quality characters of four spring oil rapeseed cultivars as influenced by population arrangements and densities. J. Agron Crop Sci., 165, 103-109.

Soleymani, A., Shahrajabia, M. H., \& Naranjani, L. (2011a). Changes of yield and yield components of canola cultivars under different plant densities and application of sulfur fertilization. Proceedings 13 Int Rapeseed Congress, June 5-9, Prague, 139-142.

Soleymani, A., Shahrajabia, M. H., Shaheri M. M., \& Naranjani, L. (2011b). The effects of sulfur fertilizer and plant densities on seed and oil yield of canola cultivars. Proceedings 13 Intl Rapeseed Congress, June 5-9, Prague, 342-345.

Zhang, S., Liao, X., Zhang,C., \& Xu, H. (2012). Influences of plant density on the seed yield and oil content of winter oilseed rape (Brassica napus L.). Industrial Crops and Products, 40, 27-32.

Vujaković, M., Marjanović-Jeromela, A., Jovičić, D., Marinković, R., Nikolić, Z., Cmobarac, J., \& Taški-Ajduković, K. (2010). Uticaj prihrane na prinos i komponente kvaliteta semena uljane repice. Ratar. Porrt., 47, 539-544.

Vujaković, M., Marjanović-Jeromela, A., Jovičić, D., Lečić, N., Marinković, R., Jakovljević, N., \& Mehandžić-Stanišić, S. (2014). Effect of plant density on seed quality and yield of oilseed rape (Brassica napus L.). Journal on Processing and Eneryy in Agriculture 18(2), 73-76. 


\section{Zavisnost kvaliteta i prinosa semena uljane repice od sklopa, sorte i godine proizvodnje}

Milka Vujaković · Ana Marjanović-Jeromela · Dušica Jovičić · Radovan Marinković

Sažetak: Uljana repica je značajna industrijska biljka u svetu. U Vojvodini se najčešće gaji na dobro aerisanim i dubokim zemljištima. Setva se najčešće vrši sa razmakom između redova $25 \mathrm{~cm}$, a u redu $5-6 \mathrm{~cm}$. Ogled sa tri genotipa ozime uljane repice (Banaćanka, Slavica i NS-H-2) je postavljen na Rimskim šančevima (Vojvodina) u vegetacionoj sezoni 2009/2010. i 2010/2011. Setva je izvršena u redove sa međurednim razmakom $25 \mathrm{~cm}$ i razmakom u redu od $5 \mathrm{~cm}, 6 \mathrm{~cm}, 8 \mathrm{~cm}, 10 \mathrm{~cm}$ i $16 \mathrm{~cm}$. Nakon žetve ispitani su sledeći parametri: klijavost semena, masa 1000 semena, zapreminska masa, prinos semena, sadržaj ulja i ukupnih proteina u semenu. U našim ispitivanjima nije utvrđen uticaj sklopa na kvalitet semena uljane repice proizvedenog u vegetacionoj sezoni 2009/10. i 2010/11. što treba imati u vidu prilikom određivanja potrebne količine semena za setvu.

Ključne reči: kvalitet semena, prinos semena, sklop, sorta, uljana repica 